\title{
Mastalgia: psychoneurosis or organic disease?
}

\author{
P E PREECE, R E MANSEL, L E HUGHES
}

British Medical fournal, 1978, 1, 29-30

\section{Summary and conclusions}

To test the traditional surgical view that pain in the breast is largely an expression of psychoneurosis, the Middlesex Hospital Questionnaire was given to 317 women with mastalgia and 170 controls with varicose veins. Their scores were compared with those of 173 women psychiatric outpatients tested by the designers of the questionnaire. The results were broadly similar in the mastalgia and varicose veins groups, and where there were significant differences women with varicose veins had a higher psychoneurotic score in each case. Within the mastalgia group no difference in scores was observed between patients with cyclical mastalgia and those with mastalgia due to periductal mastitis. Both groups of surgical outpatients had significantly lower scores in major traits than the psychiatric group, except for a small group of patients with breast pain who persistently failed to respond to treatment.

Patients with mastalgia are therefore no more "neurotic" than those with varicose veins, and differ greatly from patients with recognised psychoneurosis. Most patients have a physiological or pathological basis for their breast pain, and they deserve an appropriate diagnostic and therapeutic approach.

\section{Introduction}

Breast pain is often thought to be a psychosomatic complaint, and psychological factors have been considered among the possible causes of this common symptom. ${ }^{1}$ The commonest clinical syndromes are: cyclical pronounced mastalgia, which is related to the menstrual cycle and is notable for either its intensity or its duration; and mastalgia associated with duct ectasia or periductal mastitis, in which pain occurs consistently in the same place, though there is no temporal pattern. ${ }^{2}$

We tried to assess the degree of psychoneuroticism in women with both these types of mastalgia by comparing their scores on the Middlesex Hospital Questionnaire ${ }^{34}$ with those of patients with varicose veins.

\section{Patients and methods}

We studied 317 women whose mastalgia was severe enough to warrant investigation and treatment but excluded those who needed biopsy to rule out malignancy. One hundred and seventy women on their first visit to a varicose veins clinic acted as controls. We chose these controls because they were women outpatients of similar age to those with mastalgia who had a chronic surgical condition that was neither life-threatening nor associated with the fear of cancer.

The Middlesex Hospital Questionnaire, a simple, self-administered inventory that enables the basic psychoneurotic components of

\footnotetext{
University Department of Surgery, Welsh National School of Medicine, Cardiff

$P$ E PREECE, MB, FRCs, lecturer in surgery

R E MANSEL, MB, FRCS, research fellow

L E HUGHES, DS, FRCS, professor of surgery
}

personality to be measured quickly,,$^{34}$ was given to each woman. The components measured were: $(a)$ free-floating anxiety (anxiety without specific cause); (b) phobia; (c) obsessionalism (excessive fastidious tendencies); $(d)$ somatic anxiety (concern about bodily functions); (e) depression; and $(f)$ hysteria (this is hard to define but has been correlated with extroversion). ${ }^{5}$

The purpose of the questionnaire was explained to each patient, and she was asked to fill it in at home without help and to return it. Completed forms were marked by stencil as they were returned. The scores of the two groups of surgical outpatients were then compared with those of 173 female psychiatric outpatients of similar age, who had been tested by the questionnaire's designers and described as having neuroses or psychosomatic or personality disorders. ${ }^{6}$ We also identified a fourth group consisting of the 14 patients with mastalgia who had failed to respond to reassurance or medication with at least three different methods of treatment. Scores between the groups were compared using Student's $t$ test.

\section{Results}

Test papers were spoiled by $17(5 \%)$ patients with mastalgia and $14(8 \%)$ with varicose veins. These patients were therefore excluded from the analysis. The average age of the patients with mastalgia was 35 years, of the patients with varicose veins 38 years, of the psychiatric outpatients 34 years, and of the 14 patients with mastalgia resistant to treatment 38 years.

Total scores and scores for each trait are shown for all three groups in table I. There was little difference between the patients with mastalgia and those with varicose veins and where significant differences did occur the women with varicose veins had higher scores. The psychiatric outpatients, however, scored significantly higher than the patients with mastalgia in all traits and total score. Table II shows that the subgroup of patients persistently resistant to treatment $(4 \%$ of the mastalgia group) had scores much closer to those of the psychiatric outpatients than to those of the patients with mastalgia who responded

TABLE I-Mean ages and scores of groups $( \pm S E)$ compared

\begin{tabular}{|c|c|c|c|}
\hline Group: & Mastalgia & Varicose veins & $\begin{array}{l}\text { Psychiatric } \\
\text { outpatients }\end{array}$ \\
\hline \multirow{2}{*}{$\begin{array}{l}\text { No of patients } \\
\text { Age (years) } \\
\text { Questionnaire score: } \\
\text { Free-floating anxiety } \\
\text { Phobia } \\
\text { Obsessionalism } \\
\text { Somatic anxiety } \\
\text { Depression } \\
\text { Hysteria } \\
\text { Total score }\end{array}$} & $\begin{array}{c}300 \\
35 \cdot 1 \pm 0 \cdot 49\end{array}$ & $\begin{array}{c}156 \\
38 \cdot 3 \pm 0 \cdot 72\end{array}$ & $\begin{array}{c}173 \\
33 \cdot 8 \pm 0.82\end{array}$ \\
\hline & $\begin{array}{r}7 \cdot 6 \pm 0.23 \\
5 \cdot 0 \pm 0 \cdot 16 \\
7 \cdot 3 \pm 0 \cdot 20 \\
6 \cdot 1 \pm 0.21 \\
4 \cdot 2 \pm 0 \cdot 16 \\
3 \cdot 8 \pm 0.17 \\
34 \cdot 2 \pm 0.79\end{array}$ & $\begin{array}{c}7 \cdot 8 \pm 0 \cdot 30 \\
5 \cdot 7 \pm 0 \cdot 22^{*} \\
7 \cdot 8 \pm 0 \cdot 26 \\
6 \cdot 0 \pm 0 \cdot 36 \\
5 \cdot 1 \pm 0 \cdot 21^{* *} \\
5 \cdot 1 \pm 0 \cdot 28^{* * *} \\
36 \cdot 9 \pm 1 \cdot 07^{*}\end{array}$ & $\begin{array}{r}11 \cdot 0 \pm 0 \cdot 26^{* * *} \\
6 \cdot 8 \pm 0 \cdot 29^{* * *} \\
8 \cdot 2 \pm 0 \cdot 28^{* * *} \\
8.9 \pm 0 \cdot 29^{* * *} * \\
7 \cdot 6 \pm 0 \cdot 29^{* * *} * \\
5 \cdot 2 \pm 0 \cdot 26^{* * *} * 1^{* *} \\
47 \cdot 7 \pm 1 \cdot 71^{* * *}\end{array}$ \\
\hline
\end{tabular}

Significance of differences in each group compared with values in mastalgia group: ${ }^{*} \mathrm{P}<0.05 ;{ }^{* *} \mathrm{P}<0.01 ;{ }^{* * *} \mathrm{P}<0.001$.

TABLE II-Patients with mastalgia resistant to treatment compared with those who improved on treatment and psychiatric outpatients

\begin{tabular}{|c|c|c|c|}
\hline Group: & $\begin{array}{l}\text { Patients } \\
\text { resistant to } \\
\text { treatment }\end{array}$ & $\begin{array}{c}\text { "Improved" } \\
\text { patients } \\
\text { patia }\end{array}$ & $\begin{array}{l}\text { Psychiatric } \\
\text { outpatients }\end{array}$ \\
\hline $\begin{array}{l}\text { No of patients } \\
\text { Questionnaire score: } \\
\text { Free-floating anxiety } \\
\text { Phobia } \\
\text { Obsessionalism } \\
\text { Somatic anxiety } \\
\text { Depression } \\
\text { Hysteria } \\
\text { Total score }\end{array}$ & \begin{aligned} & \multicolumn{1}{c}{14} \\
& $10 \cdot 1 \pm 1 \cdot 20 \\
& 5.4 \pm 0.88 \\
& 8 \cdot 2 \pm 0.96 \\
& 9 \cdot 4 \pm 0.96 \\
& 5.9 \pm 0.69 \\
& 3 \cdot 1 \pm 0.82 \\
& 42 \cdot 1 \pm 4.09\end{aligned}$ & $\begin{array}{c}286 \\
7 \cdot 5 \pm 0 \cdot 23^{*} \\
5 \cdot 0 \pm 0 \cdot 17 \\
7 \cdot 3 \pm 0 \cdot 20 \\
6 \cdot 0 \pm 0 \cdot 21^{* *} \\
4 \cdot 2 \pm 0 \cdot 17^{*} \\
3 \cdot 9 \pm 0 \cdot 18 \\
33 \cdot 8 \pm 0 \cdot 80^{*}\end{array}$ & $\begin{array}{c}173 \\
11 \cdot 0 \pm 0.26 \\
6 \cdot 8 \pm 0 \cdot 29 \\
8 \cdot 2 \pm 0 \cdot 28 \\
8.9 \pm 0 \cdot 29 \\
7 \cdot 6 \pm 0.29 * \\
5 \cdot 2 \pm 0 \cdot 26^{*} \\
47 \cdot 7 \pm 1 \cdot 71\end{array}$ \\
\hline
\end{tabular}

Figures refer to mean $\pm \mathrm{SE}$.
Significance levels of $\mathrm{P}$ refer to comparison between each group and the mastalgia patients resistant to treatment: $* \mathrm{P}<0.05 ; * * \mathrm{P}<0.001$. 
to treatment. In particular, their overall scores and their scores for free-floating anxiety, somatic anxiety, and depression were significantly higher than those in the "improved" group.

A comparison of the two syndromes of mastalgia showed no significant differences in any psychoneurotic trait, although the previously reported difference in age $^{2}$ between these two syndromes was confirmed (table III).

TABLE III-Mean scores $( \pm S E)$ in different syndromes of mastalgia

\begin{tabular}{|c|c|c|c|}
\hline Type of mastalgia: & $\begin{array}{c}\text { Cyclical } \\
\text { pronounced }\end{array}$ & $\begin{array}{c}\text { Duct } \\
\text { ectasia }\end{array}$ & $\begin{array}{c}P \\
\text { value }\end{array}$ \\
\hline $\begin{array}{l}\text { No of patients } \\
\text { Age (years) }\end{array}$ & $\begin{array}{c}135 \\
34.0 \pm 0.66\end{array}$ & $\begin{array}{c}67 \\
38 \cdot 3^{ \pm 0} \cdot 95\end{array}$ & $<0.001$ \\
\hline $\begin{array}{l}\text { Free-floating anxiety } \\
\text { Phobia } \\
\text { Obsessionalism } \\
\text { Somatic anxiety } \\
\text { Depression } \\
\text { Hysteria } \\
\text { Total score }\end{array}$ & $\begin{array}{r}7.9 \pm 0.35 \\
4 \cdot 8 \pm 0 \cdot 24 \\
7.2 \pm 0.29 \\
6 \cdot 0 \pm 0.31 \\
4.2 \pm 0.25 \\
4 \cdot 1 \pm 0.28 \\
34 \cdot 1 \pm 1 \cdot 22\end{array}$ & $\begin{array}{r}8.2 \pm 0.50 \\
5.6 \pm 0.34 \\
8.0 \pm 0.40 \\
7.0 \pm 0.46 \\
5.2 \pm 0.39 \\
3.5 \pm 0.31 \\
37.2 \pm 1.69\end{array}$ & $\begin{array}{l}\text { NS } \\
\text { NS } \\
\text { NS } \\
\text { NS } \\
\text { NS } \\
\text { NS }\end{array}$ \\
\hline
\end{tabular}

NS $=$ Not significant

\section{Discussion}

Women who complain of severe breast pain have been labelled "frustrated unhappy nulliparae," and Hedley Atkins wrote $^{8}$ : "My own impression of many of these patients is the same as that of Sir Astley Cooper, that they are of an irritable and suggestive nature." These experienced workers echo the prevailing view within the medical profession that pain in the breast is merely an expression of psychoneurosis, a "psychosomatic disorder."

Our results contradict these widely held opinions. They confirm our clinical impression that most women with mastalgia are psychologically stable and suggest that in most cases aberrant physiological or pathological processes underlie the symptom. The fact that patients with duct ectasia or periductal mastitis have similar scores to patients with cyclical breast pain supports this view. Ductectasia-periductal mastitis is a welldefined clinical, radiological, and pathological condition. ${ }^{9}$ Although no organic basis has been shown for cyclical pronounced mastalgia, a hormonal abnormality seems likely. In a comparable study of the premenstrual syndrome (which is also widely thought to have a psychological basis) Rees, ${ }^{10}$ using the Maudsley Medical Questionnaire, concluded that the condition could not be dismissed as being neurotic or primarily psychogenic. We believe that a similar conclusion is inevitable for mastalgia.

Since there are several different kinds of mastalgia, it is unlikely that one single form of treatment will be universally effective. Nevertheless, even after patients had been classified according to defined syndromes and given treatments apparently appropriate to these, a few women failed to obtain relief from any treatment. As a group these women had very significantly higher scores for the two anxiety traits and for depression. Wolkind and Forrest ${ }^{11}$ in their study of the treatment of back pain found that poor responders scored significantly higher on the somatic anxiety and depression scales than the good responders, and they were able to define a cut-off point that had considerable predictive value on the likely outcome of treatment.

Results obtained with the Middlesex Hospital Questionnaire have been validated by comparison with established inventories, ${ }^{12} 13$ and populations identified with the questionnaire correlate well with those defined by other criteria. The questionnaire has been used to show higher somatic anxiety in patients who do not respond well to treatment for back pain ${ }^{11}$ and low levels of anxiety in obese patients. ${ }^{14}$ Since it is simple to use, the Middlesex Hospital Questionnaire may be useful in clinical practice for identifying patients who are likely to respond poorly to conventional treatment. Particularly in conditions such as mastalgia, where there are few objective criteria to measure, routine use of the Middlesex Hospital Questionnaire provides an additional index for assessment. We are performing further studies to see whether the use of this questionnaire may clarify at an early stage whether psychiatric advice may be more appropriate than, for example, surgery. In this way, the patient will receive appropriate help from the outset, time and resources will be saved, and effective treatments will not fall into disrepute because of inappropriate application.

We thank Mr A G Karseras for introducing us to the Middlesex Hospital Questionnaire. This study has been made possible by the work of Mrs Edna Lewis, who has given regular time for meeting and explaining the questionnaire to the controls. We also thank Mr R G Newcombe for statistical advice and Mrs Barbara Holland for secretarial help. The project was financed by the Medical Research Council.

\section{References}

1 Patey, D H, British Medical fournal, 1949, 1, 96.

2 Preece, P E, et al, Lancet, 1976, 2, 670.

${ }^{3}$ Crown, S, and Crisp, A H, British fournal of Psychiatry, 1966, 112, 917.

${ }^{4}$ Crown, A, Duncan, K P, and Howell, R W, British fournal of Psychiatry, 1970, 116, 33

${ }^{5}$ Cockett, R, British fournal of Psychiatry, 1969, 115, 1141.

${ }^{6}$ Crown, S, and Crisp, A H, Manual of the Middlesex Hospital Questionnaire, p 16. Barnstaple. Psychological Test Publications, 1970.

7 Jeffcoate, N, Principles of Gynaecology, 4th edn, p 550 . London, Butterworths, 1975.

${ }^{8}$ Atkins, H J B, Lancet, 1938, 1, 707.

${ }^{9}$ Ingleby, $\mathrm{H}$, and Gershon-Cohen, J, Comparative Anatomy, Pathology and Roentgenology of the Breast, p 237. Philadelphia, University of Pennsylvania Press, 1960.

${ }^{10}$ Rees, L, fournal of Mental Science, 1953, 99, 62.

${ }^{11}$ Wolkind, S N, and Forrest, A J, Postgraduate Medical fournal, 1972, 48, 76.

12 Young, J P R, Fenton, G W, and Lader, M H, British fournal of Psychiatry, 1971, 119, 393.

${ }^{13}$ Olley, M, and McAllister, H, Psychological Medicine, 1974, 4, 463.

${ }^{14}$ Crisp, A H, and McGuiness, B, British Medical fournal, 1976, 1, 7 .

(Accepted 14 October 1977)

ONE HUNDRED YEARS AGO The Aberlour succession case came on for trial in the Edinburgh Court of Sessions last week, and was finally closed by compromise. The pursuer, Mrs Yeatman, née Temple (who jilted her friend Miss Macpherson Grant, to whom she was solemnly pledged to live single until death should them part), agreed to accept $£ 10000$, and withdrew all claims henceforth and for ever. Miss Grant, never forgiving the defection, revoked the will leaving everything to her friend, and shortly afterwards died intestate. This settlement of the will in dispute brings about a remarkable change in the fortunes of a medical practitioner in the village of Rhynie, Aberdeenshire, who suddenly rises from obscurity and a humble practice to take up, by right of succession, the responsibilities and position of a Highland laird. Dr Proctor, first cousin of deceased, and heir at law, is now at liberty to transport his wife and eight children from Aberdeenshire across his own broad acres in the neighbouring county of Banffshire, to enter the lordly halls of Aberlour House as master. Twenty-two years ago, the change of position was quite as singular for the last proprietor, who was the only child of an equally obscure medical practitioner in a Scotch village, and was left the estate by her uncle, Mr Grant, a rich West Indian planter. The grounds of Aberlour House are guarded on east and west by picturesque lodges, beyond which stretch miles of beautifully kept carriage drives and avenues. The river Spey, with many a glorious salmon pool, bounds the property on the north; and behind the house, which stands on elevated ground, and ascending further still, you suddenly emerge upon a glittering mass of highly cultivated garden. It stands, with its miniature crystal palace, like an oasis in the surrounding moorland, from which it has been reclaimed. Instead, however, of making a state entry on this beautiful estate, we understand it is Dr Proctor's intention simply to remove his door-plate from the village of Rhynie to the town of Aberdeen, there to continue the profession he enjoys. (British Medical fournal, 1878.) 